\title{
Om sommarkurserna i Kreativt skrivande
}

\author{
Magnus Eriksson
}

\section{Historik och förutsättningar}

Vi har erbjudit tre sommarkurser i Kreativt skrivande. "Att skriva historiska romaner” gav vi första gången 2009. Sedan följde en propedeutisk kurs om att skriva för barn, närmast avsedd som en förberedelse för kursen "Att skriva barnlitteratur”, som löper över höst- och vårterminerna. Sommaren 2014 gav vi för första gången kursen "Kreativt skrivande: en introduktion”, som söktes av 5000 studenter. Den förstnämnda kursen gavs på heltid, de första åren dessutom med obligatoriska heldagsträffar som inledning och avslutning. De två senare kurserna har getts på halvtid och heldistans, alltså utan träffar på campus. "Kreativt skrivande: En introduktion” är den enda av dessa kurser vi för närvarande ger som sommarkurs. Att skriva historiska romaner fick en fortsättning efter ett par år, ”Att skriva historiska romaner II” som gavs under ordinarie termin. När Kreativt skrivande blev ett eget ämne på Institutionen för film och litteratur slogs de två nivåerna samman till en kurs om 30 högskolepoäng som liksom de flesta av våra andra kurser löpt över två terminer. Den kursen ligger dock på is efter läsåret 2014-2015. Den svarade mot ett konkret behov i tiden. Vi hade mer än 100 studenter första gången den gavs, färre än tio den senaste gången.

Nästan all undervisning i Kreativt skrivande på Linnéuniversitetet sker på distans. Pedagogiskt har det många fördelar. Visserligen åtnjuter det så kallade textsamtalet hög status i skrivpedagogiken, men att arbeta över nätet ger en tydligare konstans i arbetet. När handledningen sker skriftligt kan vi som lärare inte komma undan med allmänna fraser som "det här ser lovande ut” eller "fortsätter du på den här linjen blir det bra”. Även de mer kvalificerade kommentarer som ges i de muntliga textsamtalen kan lätt bli ett jagande efter vind, när studenten funderar på vad som egentligen sades. Där har den skriftliga handledningen avgjorda fördelar. Den skriftliga formen ställer högre krav på precision och konkretion i kommentarerna. Studenten kan dessutom återvända till vad handledaren skrev vid föregående textinlämningstillfällen. Läraren kan inte komma undan med uppmuntrande men tomma fraser eller abstrakt hållna omdömen, vilket är enklare vid muntlig handledning; det är naturligtvis inte regel vid sådan, men en risk. Skriftlig handledning ger dessutom studenten större rättssäkerhet, då studenten alltid kan hänvisa till vad handledaren skrivit.

Jag skall dock inte förringa textsamtalen. De har ett värde. De äger vanligen rum i grupp, och på våra kurser på högre nivå är de en del av verksamheten; de kurserna ges på halvdistans, och då blir textsamtalen ett komplement till skriftlig handledning och forumdiskussioner med kurskamraterna om manus under arbete.

\section{Heldistans eller halvdistans?}

När det gäller våra sommarkurser är även frågan om hel- eller halvdistans av vikt. För egen del har jag bara goda erfarenheter av undervisning på heldistans, alltså kurser där studenterna aldrig träffas på campus. Fördelarna blev tydliga på en kritikkurs som vi för en del år sedan 
lade över från halvdistans till heldistans. Det var då en kurs på grundläggande nivå. Ett moment i kursen kallade jag för "Recensionens anatomi”. Det var en analys av recensionsartikelns skilda aspekter: kontext, referat/beskrivning, tolkning/analys, värdering. De olika aspekterna glider ofta in i varandra, men de kan också vara klart urskiljbara inslag som kan avgränsas från varandra. En recension behöver inte heller omfatta alla. Syftet med analysen var att skärpa studenternas blick för vad en recension innehåller och det inre sambandet mellan dess skilda aspekter. När kursen gick på halvdistans ägnades en del av ett föreläsningspass åt uppgiften. Studenterna fick ut ett par bokrecensioner som de skulle analysera för att isolera de skilda aspekterna men också för att se hur dessa samspelar med varandra. När uppgiften gavs i föreläsningssal fick vi fina analyser av kursens mest aktiva kritiker. De andra följde med i resonemangen, nickade instämmande och flikade ibland också in eller annan klok kommentar. Resonemangen fördes muntligt.

När kursen gjordes om till heldistanskurs, lades föreläsningen om de skilda aspekterna av recensionen ut som bakgrundsmaterial på lärplattformen. Sedan fick studenterna skriftligt analysera skilda recensioner och kritiskt jämföra dem. Jag var osäker inför omläggningen av kursen. Jag uppskattar direktkontakten med studenter och ser den som en viktig del av det arbete som utförs, även om merparten av detta utförs på nätet. Jag blev dock positivt överraskad. När alla tvingades att skriftligt formulera sina analytiska och kritiska iakttagelser blev deras egna recensionsuppgifter totalt sett bättre. De bästa artiklarna var på samma nivå som tidigare, men de övriga studenterna visade i sina egna texter ett mer reflekterat förhållande till recensionen som genre och ökad lyhördhet för sambandet mellan beskrivning och analys å ena sidan och kritisk värdering å den andra. Den teoretiska medvetenheten stärktes alltså märkbart när kursen blev en heldistanskurs. Föreläsningen (jag tar mig friheten att kalla det skrivna bakgrundsmaterialet med formulerad uppgift för en "föreläsning”) fungerar på nätet, medan den i en föreläsningssal utövar mer selektiv verkan.

\section{Ämnets pedagogik och förståelsemodell}

Mycket av undervisningen i Kreativt skrivande, främst handledningen, präglas av en emergent, eller framväxande, förståelse av det slag som tolkningsfilosofen Mats Furberg teoretiserat (1982: 206-210). Det är en hermeneutisk process i vilken båda parterna i ett samtal, eller i ett meningsutbyte med pedagogiska ambitioner, uppnår djupare förståelse av ett fenomen genom ömsesidigt utbyte av idéer och erfarenheter. Som lärare i Kreativt skrivande möter jag studenternas texter med mina estetiska och kritiska idéer. Men i mötet med dessa texter måste jag också konfrontera mina egna idéer. Det kan jämföras med den derrideanska idén om "det bottenlösa schackbrädet”, alltså en ändlös process genom vilken nya skikt av mening öppnas i en oupphörlig rörelse där tiden också antar rumslig karaktär (Hoy 1978: 77-84). Leslie Thomson skriver att läraren i Kreativt skrivande gör en "double journey”. Studenten lär sig att skriva, läraren lär sig att bli lärare: ”Like the students, I have had to undergo loss as I take on new concepts” (Thomson 2013: 46). Lärarens estetik och litterära förståelse förändras genom det kritiska arbetet med studenternas texter. "I have learnt and am still relearning”, skriver Thomson (Thomson 2013: 46). Därför kan varken ämnets hermeneutik eller dess pedagogik fixeras. Det finns inga givna idéer som ger det kritiska och pedagogiska arbetet en helt igenom överblickbar grund. 
Syftet med undervisningen i Kreativt skrivande är att göra studenterna till författare, eller till bättre författare, eller bättre kritiker och essäister. Nicole Cooley har formulerat målet i termer av "experience", "voice”, "authority” och "essentialism” (Cooley 2003: 100). Hon diskuterar dessa i ett mer avgränsat sammanhang, i en kritisk uppgörelse med kraven på anonymisering av studenternas texter för en påstått opartisk bedömning av dem. Men kategorierna kan även användas för att beskriva undervisningens mål, även om "essentialism" är ett belastat ord. Cooley ser det som ett resultat av de tre andra kategorierna i växelspel. Den som vill kan relatera till den ryska formalismens term "litteraritet”.

Alltså, genom samspelet mellan handledare och student växer fördjupad förståelse fram. Studenten blir en bättre författare, eller bättre på att bemästra text och uttrycksmedel för att tolka erfarenhet i en röst, i den egna rösten. I våra längre kurser är detta en process som kan löpa över flera år, från grundläggande till avancerad nivå. Det är en process som kräver tid och kontinuerlig kontakt, uppgifter och omsorgsfulla kommentarer. Den kritiska frågan för sommarkursernas vidkommande blir då: Hur uppnår vi detta under tio veckor på halvtid?

Vår första sommarkurs i Kreativt skrivande, ”Att skriva historiska romaner”, löpte visserligen på heltid, men den var felplanerad det första året. Det hade utvecklats ett mönster, som passade de teoretiska sommarkurserna. Internt kallade vi dem "brevlådekurser”. Det innebar att studenterna sattes igång, fick ett läspensum och en avslutande paperuppgift. Beskrivningen och benämningen må vara vanvördiga, men de saknar inte täckning. Beskrivningen ska inte heller nödvändigtvis uppfattas som kritisk. Upplägget var ändamålsenligt för en viss typ av kurser, där det gällde att läsa och smälta nya intryck och kunskaper för att sedan redovisa dem i ett problemorienterat perspektiv. Däremot passade de inte en kurs i Kreativt skrivande. En heldag med föreläsningar om historiska romaner, sedan hem och skriva början på en sådan och lämna in manus tio veckor senare; det säger sig självt att det som behövs för att hjälpa studenten att finna sin röst, sitt stoff och sina uttrycksmedel inte rymdes i en sådan kursplanering. När kursen gavs nästa gång hade också planeringen ändrats och anpassats till de arbetssätt vi vanligen använder i ämnet.

För att en kurs i Kreativt skrivande skall fungera på önskvärt sätt krävs tid för skrivande, tid för handledning och kritiskt meningsutbyte och på grundläggande nivåer också konkreta och väl varierade uppgifter som hjälper studenten att finslipa sina uttrycksmedel och tematiska idéer. Dessutom skall studenten läsa böcker, både skönlitterära och facklitteratur om skrivande - för inspiration, orientering och reflektion. En viktig del är vidare studentens kritiska läsning av sina kamraters texter. Det ger värdefulla synpunkter för författaren till den kommenterade texten, men den kritiska granskningen av svagheter och förtjänster i andras texter skärper även blicken för det egna skrivandet.

Allt detta ryms knappast i en kurs som löper på halvtid över tio veckor, inte heller om den ges på heltid. Det är ju dessutom sommar ...

\section{Att finna ett lämpligt format för en sommarkurs i Kreativt skrivande}

Kursen "Kreativt skrivande: en introduktion” kan ytligt se ut som en uttunnad version av den första terminen av vår kurs på nivån 1-30 högskolepoäng. Den rymmer ett antal korta skrivuppgifter, både tekniska och tematiska. En dialog skall skrivas, en person och miljö beskrivas, men vi har också arbetat med en tematisk uppgift och en romananalys. Uppgifterna 
har flera syften, både formella och andra, mer undflyende. Fantasin skall flöda, men en dialog måste också konstrueras på ett korrekt sätt. Skiljetecknen skall in på rätt plats i förhållande till anföringstecken, word må ställas om så att det inte blir jämn vänstermarginal till höger om talstrecket ifall sådant används. Det senare är en del av word-förbannelsen, alltså förinställda format som inte tar hänsyn till våra kurser på Linnéuniversitet. Tala om Gates of Hell ...

Formalismen är inte ett självändamål. Kurserna, vilken nivå vi än arbetar på, skall även förbereda studenterna på framtida kontakter med förlagen. Ju fler onödiga skönhetsfel, desto mindre chans att även väl kvalificerade manus inte går vidare i förlagshanteringen.

Men formalismen är bara ett syfte. Just en dialoguppgift skall också träna studenterna på att använda repliker och anföringssatser för mer än direkt informationsöverföring. Förutom att tala om för läsaren vad någon säger, skall dialogen också förmedla intryck av känslor, temperament, relationer och reaktioner. Den fungerar även på en symptomal nivå. Det handlar inte bara om vad som sägs, utan också om hur det sägs. Dessutom är dialogen ett hjälpmedel för temposkiftningar $i$ texten. Det kan behövas om miljö- och personbeskrivningar blir alltför utdragna, en återkommande tendens hos studenter som just börjat söka sina uttrycksmedel.

Genom ett par korta uppgifter skall studenterna alltså tränas att använda de tekniska greppen på ett informationstätt och associativt sätt. Deras blick för möjligheterna att göra de tekniska greppen, eller textens formella aspekter, betydelsebärande skall skärpas. Vad som i förstone ser ut som isolerade tekniska övningar, kommer genom kursen att knytas samman. Även en kort sommarkurs utmynnar i skrivandet av en sammanhängande text. Det kan vara en novell, inledningen på en roman, eller en diktsvit, även om just den aktuella sommarkursen fått slagsida mot prosaskrivandet.

Att utforma uppgifter som leder studenten mot ett förverkligande av Cooleys värden "experience”, "voice”, "authority” och "essentialism” är i allra högsta grad möjligt även på en kort sommarkurs. Det gäller att hålla dem på en hanterbar nivå, eller ett begränsat omfång. För en introducerande dialog som fyller de syften jag nämnt kan 30 - 40 repliker utan vidare räcka. En miljöbeskrivning eller personintroduktion kan också göras relativt kort. Eller snarare: bör göras relativt kort. Inte minst för de senare övningarna gäller det för studenten att noga väga vad hen vill ha sagt. Den receptionsestetiska idén om läsarens medskapande ställer krav på koncentration och fokusering. Ingen läsare vill ha allt skrivet på näsan, och en viktig uppgift för läraren på inledande kurser är att få studenten att tydligare se vad som inte behöver sägas; det gäller både prosa, lyrik och dramatik. För att ta ett elementärt exempel: i början av en kurs fylls beskrivningarna av onödiga adjektiv och adverb. Att få studenten att lita på orden är en viktig uppgift på en introduktionskurs. Eller om syftet är språkkritiskt: att lita på den underminerande verkan som finns i orden utan att dessa måste kvalificeras med en adverbiell räcka. Prefixet "o-" har ändock en absolut, negerande betydelse. Den som skriver att en gestalt är "helt olycklig” riskerar att sudda ut denna. Det utarmar språket, inte endast det litterära språket.

De här exemplen kan förefalla petiga, men det är ofta på den nivån vi måste börja för att studenten skall utveckla ett litterärt språk, eller sin "voice” för att anknyta till Cooley. Det är också något som låter sig göra på en i tiden starkt avgränsad kurs, till exempel en sommarkurs på halvtid. Men det är naturligtvis bara en början. 
Anpassade uppgifter och täta kontakter mellan student och lärare är kanske vad som ytterst legitimerar en sommarkurs i Kreativt skrivande. Det ställer krav på lärarens arbetsinsats. Kommentarerna måste vara fokuserade, de kan inte slarvas igenom hur mycket solen än skiner. Att demoraliseras av bad och solsken är studentens privilegium.

Jag skrev att en kurs i Kreativt skrivande kräver "tid för skrivande”. Om uppgifterna är precist formulerade och omfångsmässigt rimligt begränsade ges tid även inom ramen för en sommarkurs. Men studenten måste då också få möjlighet att koncentrera sig på sitt eget skrivande, inte på andras. Hur värdefullt det än är för utvecklandet av den kritiska, och självkritiska, förmågan att kommentera kamraternas texter är det något som bör uteslutas på en kort kurs. Det är i alla fall min erfarenhet. För att kommentera andras texter måste studenten snabbt skifta perspektiv och gå in i de andras skrivande, för att sedan återgå till sitt eget skrivande. Det är en process som tar en del tid, och den tiden finns sällan på en sommarkurs. På de längre kurser som löper över höst- och vårterminerna finns även uppgifter av teoretisk eller litteraturhistorisk art som skall göras. De kan förenas med det egna skrivandet och kommenterandet. Att skifta perspektiv tar tid, men det skall inte ge tidsspillan. På sommarkursen måste däremot uppmärksamheten riktas åt ett enda håll: eget skrivande och läsande.

Sommarkurserna är en värdefull del av kursutbudet, även i Kreativt skrivande. Vi har haft många studenter på våra längre kurser som började med en sommarkurs. De ger också en möjlighet för dem som inte kan satsa på en längre kurs att pröva och utveckla sina litterära idéer och uttrycksmedel. Och, inte minst viktigt, liksom de renodlat teoretiska sommarkurserna fungerar de för många unga studenter som en akademisk inkörsport innan de går över till tyngre varor.

\section{Slutord}

Det gäller dock att använda tiden effektivt. Tio veckor är inte automatiskt en halvering av de andra terminernas tjugo veckor. Det innebär också en kvalitativ förändring. Det koncentrerade arbetet innebär tätare kontakter med handledaren, vilket delvis kan kompensera den begränsade tidsramen. Även det i tiden begränsade meningsutbytet präglas idealt av en förståelseemergent kunskapsprocess, både i Furbergs betydelse av termen och i Thomsons idé om studentens och lärarens ömsesidiga lärande i ämnet.

Däremot tror jag inte att den korta sommarkursen tillåter bredare, litterära perspektiv. Kursen "Kreativt skrivande: en introduktion” är just en introduktion. Kursen om att skriva för barn motiverades som en förberedelse för de arbetsprov som användes vid urvals- och antagningsprocessen till den ordinarie kursen "Att skriva barnlitteratur”. Kursen ”Att skriva historiska romaner” fick snart sin fortsättning under höst- och vårterminen. Den byggdes ut och byggdes även in i den pyramidstruktur som präglar ämnet Kreativt skrivande på Linnéuniversitetet, som en av flera kurser på nivån 1-30 högskolepoäng som ger behörighet att söka kurser på högre nivå.

Jag tror också att sommarkursformatet bäst lämpar sig för kurser med begränsad syftning, tematiska eller genregrundade. I framtiden kanske kurser som ”Att skriva lyrik”, ”Att skriva deckare”, "Att skriva noveller” eller "Att skriva sånglyrik" vore en möjlighet. Men även 
tematiska kurser inriktade på till exempel samhällskritik, skräck eller erotik kan dyka upp. De kan också vara en inkörsport.

\section{Referenser}

Cooley, Nicole (2003), "Literary Legacies and Critical Transformations: Teaching Creative Writing in the Public Urban University”, Pedagogy, Vol. 3, No. 1, s. 99-114.

Furberg, Mats (1982), Säga, förstå, tolka. Till yttrandets och texters problem. Bodafors: Doxa.

Hoy, David Couzens (1978), The Critical Circle. Literature and History in Contemporary Hermeneutics. Berkeley: University of California Press.

Thomson, Lesley (2013), "Learning to Teach Creative Writing””, Changing English, Vol. 20, No. 1 , s. $45-52$. 